\title{
Urban Art Scene in Madrid "How Can a Contemporary Art Be Used for Tourism?"
}

\author{
Punartha Perera
}

Catholic University of Leuven, Belgium

Copyright $@ 2019$ by authors, all rights reserved. Authors agree that this article remains permanently open access under the terms of the Creative Commons Attribution License 4.0 International License

\begin{abstract}
Urban art (UA) is a contemporary art type, which was developed in the past four to five decades. Gradually with time, various UA types have been increasingly visible in many cities. While UA growth in certain cities has been faster, the progression of this art type in most cities has faced oppositions from various groups and thereby been slower. This research studies the current context of progression of UA scene in Madrid, considering Madrid as the case study. The research further explores the capability that UA could demonstrate as a tourism development tool in Madrid. Based on the capacity existent for UA being used as a tourism tool, the research suggests ways on how UA can be of best use for the society as a tourism tool. The research also aims to find out what categories of participants in the society should be benefited from UA scene being used for the tourism development in Madrid. The research is carried out using a qualitative research methodology and through an exploratory approach. The research is completed with the use of more primary source data together with additional secondary sources of data. Observations, short questionnaires and interviews are main primary source data gathering instruments while document analysis is the main instrument in processing secondary source data. The results show that Madrid is in a city full of UA types all around the city and has the definite capability to be further developed as a tourism tool. The urban artists are involving in creating their own UA pieces both legally as well as illegally while facing obstacles from the authorities, even though impediments have reduced from 2015 due to the new local government. However, the research concludes that Madrid's UA can be further developed through the continued support from policy makers and by giving the direct benefits of the development to local artists and the local UA stakeholders. The steps taken for the advancement of UA in Madrid will have an explicit effect also on its growth as a tourism development tool.
\end{abstract}

Keywords Urban Art (UA), Piece, Graffiti, Tag, Urban Artists, Urban Art Tourism, Tourism Development Plan, Madrid

\section{Introduction}

In Europe and the Americas one sees how UA has beautified city environments through artistic impressions. As the opportunity arose the researcher decided to investigate further on this relatively new term of UA and relate UA to tourism. The interest in UA in a Spanish context helped to choose Madrid as a case study city and to research further on UA in this city. The decision was taken to investigate the current context of UA in Madrid and also to research on how UA can be used as a tourism development tool. Based on these fundamental remarks, the research was initiated.

\subsection{Problem Setting}

Madrid is the capital city of Spain and considered as an important tourist destination. It is the 23rd mostly visited city in the world (The local, 2015) where 4.5 million tourists visited it in 2014 (statistica.com, 2016)1. The city has many attractions for the tourist to experience the grandeur of the Spanish capital such as various museums, parks, markets and historic buildings.

Spain was affected by the 2007-2009 global economic downturn (recession) heavily, impacting every realm of life. Madrid was no exception. In the midst of chaos in the city, some Madrilenians (inhabitants in Madrid) among peers in other cities, found a creative and a positive way to express their ideas in a non-violent way and one of these forms was creating UA forms.

On the other hand, the UA scene in Madrid has been facing obstacles in the recent past hindering its development. UA had been considered by the local government of Madrid as an attempt of vandalism to

1Obtained from http://www.statista.com/statistics/449249/yearly-numbe r-ofinternational-tourists-visiting-madrid-2001-2014/ 
disrupt the normal lifestyles of people through mob activity (Aguirre, 2015). The attitude of the government had been seen through many instances of recent arrests of artists who have been drawing on walls and on other public transport services (Euro news, 2013).

The situation where UA is attracting tourists but receives less support from the government brings forward an important question. The question lies on whether there is a possibility of using the UA scene in these cities as a tourism development tool cooperating with government and to find out how these tourism benefits can be derived. Therefore, considering Madrid as a case study city for UA, this research investigates the potential of UA in Madrid and how it can be further developed.

\subsection{Research Questions}

The main aim of this research is to find out how the UA scene in Madrid can be of further benefit for developing tourism in the city. The research aimed to find out the manners from which the tourism can benefit from UA and also the stakeholder groups who should be benefited from UA tourism in Madrid. The main research question is,

"Does urban art in Madrid have the capacity to be developed as an attraction for the visitor who comes to Madrid and, if that is so, how and through whom can these capacities be realized?"

In the process to answer the main research questions, the research will aim to answer the following,

- Which forms of UA are present and in which neighbourhoods in the city? Is UA in Madrid unique compared to other cities? How does UA relate to the city's law as well as the current tourism development plan? How are the urban artists involved in creating their art pieces in Madrid? Are there any obstacles faced by urban artists through administrative authorities?

- What is the perception of different segment of people on Madrid's UA as a tourism tool? What are the gaps existing among the perceptions among UA stakeholders?

- What is/are the way/s that UA in Madrid can be further related to the city's tourism development plan through the policy makers? What other general value additions can the policy makers implement for the UA tourism in Madrid?

Through the answers to the sub questions, this research plans to find concrete solutions the main research questions. The sub questions are aimed at giving a leading path to the final answer, highlighting the tourism value of the UA in Madrid from each stakeholder point of view.

In the second part, the theoretical framework will be explored, in the third part the research methodology and thereafter in the fourth part the research findings. The last part is dedicated to give policy measures to officials.

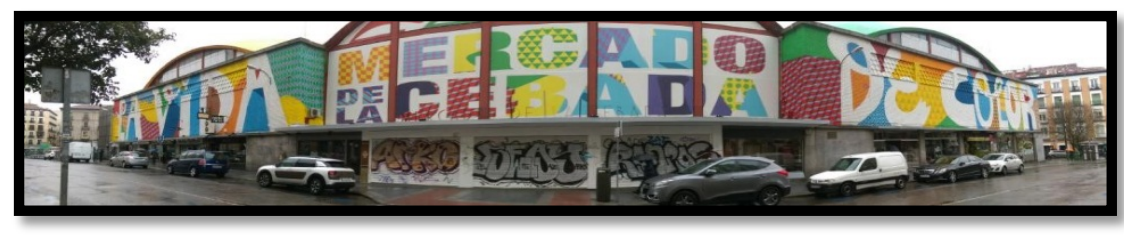

Image 1. Legal UA murals, El Cebada market, Madrid (Source; researcher)

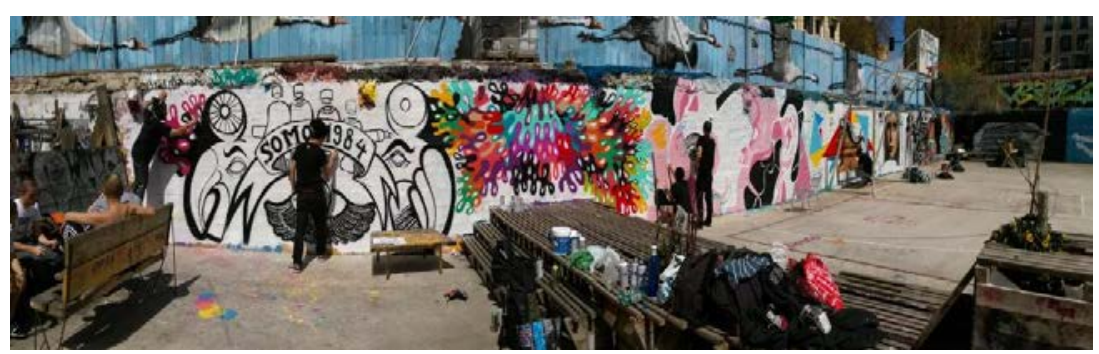

Image 2. Legal urban artists painting in La Latina community center, Madrid (Source; researcher)

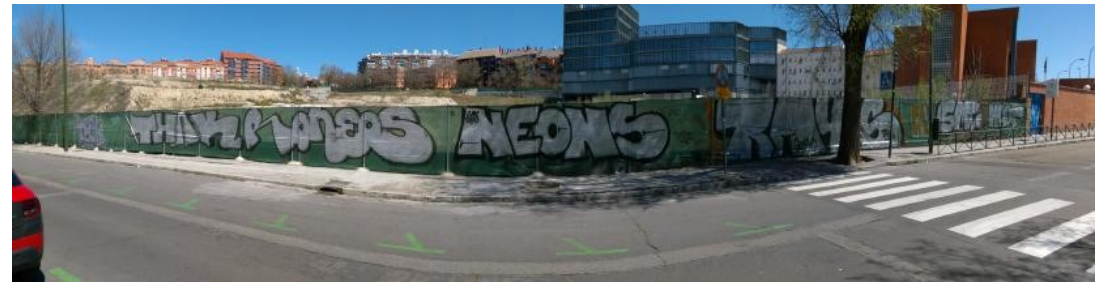

Image 3. Tagging in Ventas, Madrid (Source, Researcher) 


\section{Theoretical Framework}

The previous part offered an introduction to the topic at hand. It is not practical to speculate on the answers to the research problem presented without first examining the relevant literature of the questions under investigation. This part explores the scholarly articles on UA and UA tourism.

\subsection{Urban Art (UA)}

\subsubsection{Definition of UA and Related Arts}

Identifying a specific definition for UA is never an easy task since each scholar specifies a different definition according the context. Urban art, originally introduced by Allan Schwartzman in 1985 (Lewisohn, 2008) is an all-encompassing varied artistic expression against an urban backdrop, deriving directly from graffiti art, in a two or three-dimensional state. Since then, UA has been continuously being used in various scholarly contexts, specially extravagating in the last decade. Belgun (2013) simplifies the meaning of UA as a type of visual art created in and around urban spaces. This definition gives attribution to UA, where there were also other new names suggested for usage such as guerrilla art and neo graffiti (Irvine, 2012).

\subsubsection{Types of UA}

Urban artists create a variety of types (forms) of art pieces. Ganz (2006) mentions that most modern urban artists have liberated themselves from relying solely on spray paint (which is the only ingredient necessary for graffiti) by creating different UA types. Each type of UA has its own characteristics and is unique. The following section further describes these art types.

Tagging is the most common and the oldest type of urban art form (Image 3). It is an art type where the artist writes his name through letters or through another form, such as a symbol. One immediately recognizes as graffiti on the street is mostly tagging (Hughes, 2009).

Bombing of yarn bombing (Images $4 \& 5$ ) is a way of tagging or spray-painting multiple surfaces within one location, often using quick tags (Hughes, 2009). Yarn bombing is an appealing way for the youth and is seen in its novelty as a visual representation with a unique and holistic aesthetic form (Kan, 2001, p.21).

Stickers have been an easy of way of UA propagation. This fast art form is created through placing a sticker to disseminate an image, message or a tag. Stickers are mostly seen in poles, doors, bank cash machines, benches and subways (Allen, 2015).

Wheat pasted poster (Image 6) can be defined as an adhesive made from mixing equal parts of flour and water. The artist covers an area with the paste and then unfurls a poster. Beforehand, he removes the wrinkles and the bubbles in the paste (Keys, 2008, p. 98).
Street installation is a site-specific art form (Image 7), and is often created in a three-dimensional or sculptural form (Allen, 2015). Varying from being temporary to permanent, street installations may combine several techniques of the urban art forms. Installations can have a visual illusion.

Stencil graffiti (Image 8) is a paper or cardboard cut design, which is thereafter spray-painted onto a wall. A stencil is usually a phrase, an image, or a combination of both (Allen, 2015). Some stencil graffiti forms are repeated around a specific geographic area while many are one-off.

Legal walls have been one of the best types of UA through which urban artists have gained official recognition and empowerment (Lewisohn, 2008). As the name suggests, this type of art is legal and created with permission from property owners and even entire neighbourhoods.
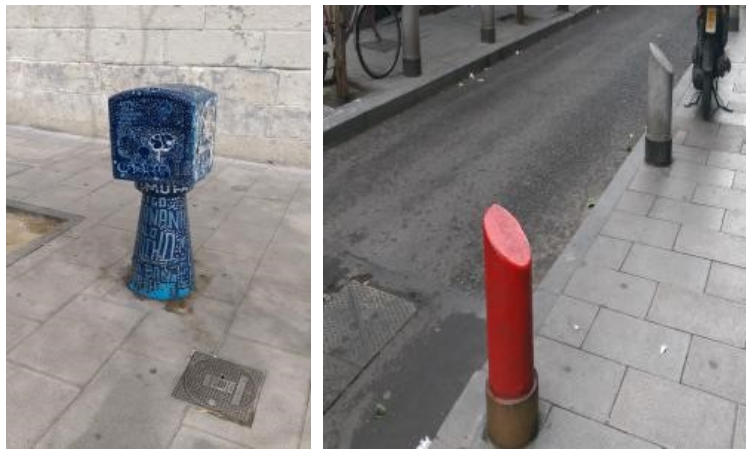

Image 4 \& 5. Yarn bombing in El Rastro and Embajadores, Madrid (Source, Researcher)

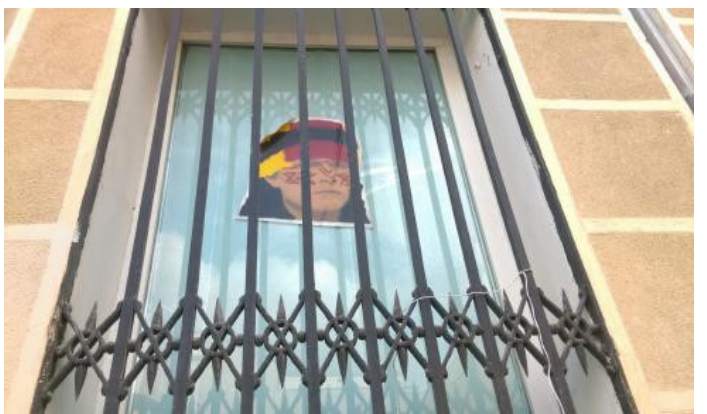

Image 6. Wheat Paste Poster in El Rastro, Madrid (Source, Researcher)

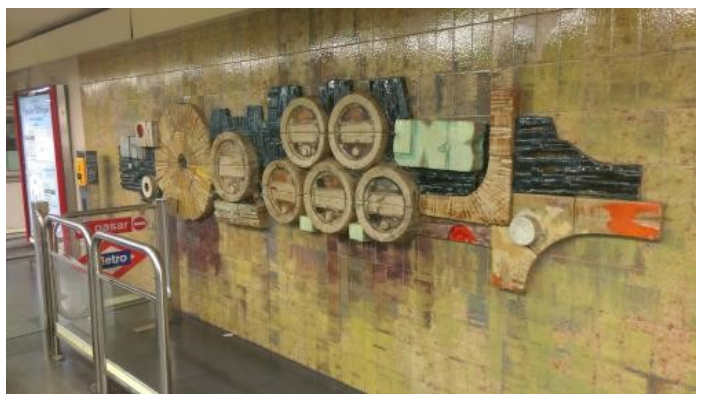

Image 7. Street Installation in Malasana metro station, Madrid (Source, Researcher) 


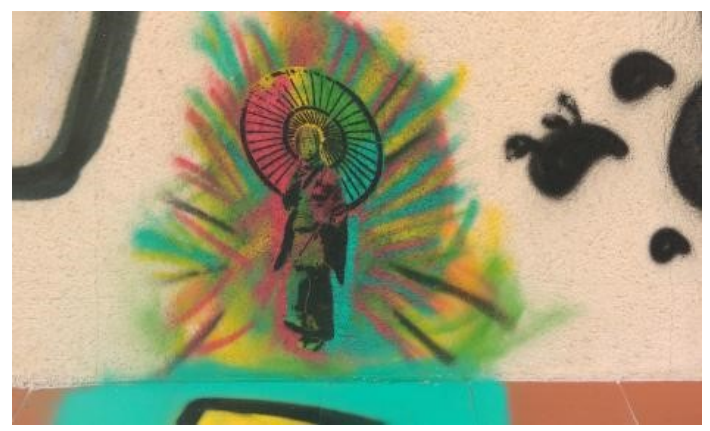

Image 8. Stencil graffiti in El Rastro, Madrid (Source, Researcher)

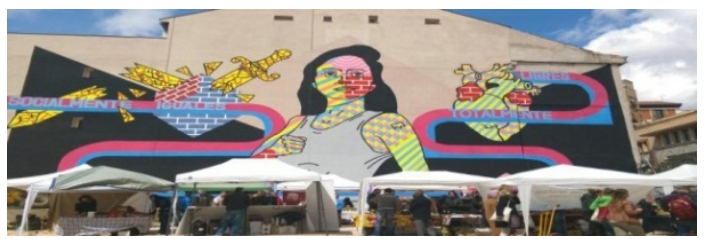

Image 9. Legal walls in El Rastro, Madrid (Source, Researcher)

\subsection{Urban Art and Tourism}

\subsubsection{Role of UA as a Tourism Tool}

There are countries where the hidden aspect of UA tourism is intentionally brought up during political unrest periods (Neves \& Semoes, 2015) such as Tunisia, Israel and Egypt. More importantly, the growing interest of tourists who specifically want to look at UA pieces act as a niche segment and back the importance of this type of art as a tool for tourism. The increasing popularity of UA (Edwards, 2015) has brought tourists to participate in an UA tour in cities.

\subsubsection{UA Tourism in Capital Cities}

UA is an art type prevalent mostly in city environments (Lewisohn, 2008; Belgun, 2013). This section will take into account how UA tourism has been manipulated in Latin America and in Europe considering 2 examples.

Bogota is the capital of Colombia and was a city where UA was considered to be illegal and sanctioned. In 2011, the killing of a 16 year old urban artist by a policeman had created a huge social tension which caused the mayor in the city, in 2013, to issue a decree supporting and promoting UA as a sign of cultural and artistic expression (The guardian, 2013). The published decree defined the specific locations in Bogota for urban artists. The decree was positively followed up through various private and government companies, who hired selected urban artists to be given the chance to decorate certain parts of city walls. Bogota's liberal attitude on the UA scene has assisted to increase the number of art-lover tourists to visit the city in the recent past (The guardian, 2013). The liberal attitude of the government also has helped local urban artists to lead UA tours in the neighbourhoods of Bogota with tourists. Recently, popular singer Justin Bieber also created his art piece after a concert in Bogota. The government in
Argentina had declared certain parts in its capital, Buenos Aires, to be open for UA and therefore it is considered to be the most supportive city for UA in Latin America (Braun, 2014).

Walking down Old Street in the neighbourhood of Shoreditch in London, one will come upon a brick building covered in awe-inspiring UA pieces. These are paintings by some of the most famous urban artists in the world such as Banksy, Stick, and ROA. However, London's UA scene has gone through a long struggle to achieve the current recognition. Over the years, the urban artists had been facing hindrances from the authorities to stop spread this new scene of contemporary art but at the end the sheer determination has helped some parts of London to be the state of the art UA localities, where UA is freely practiced without objections (Elsworth-Jones,2013). Part of this revolutionary change is owed to the world famous urban artist, Banksy. He has been maintaining an underground profile and creating different types of UA pieces in London from 2003. Banksy continued to propagate messages of political and social communication through his art pieces without the public letting knowing his true identity. It was when Banksy was selected as one of the 'Times hundred most influential people in the world ${ }^{2}$ in 2010 that London recognized the importance of UA and how it has the capacity to reach a powerful global audience. Since then, Banksy's UA pieces have shifted from the streets to art galleries to museums.

London's official tourism site is now openly encouraging visitors to see the UA in the city and guides the visitor by directing to graffiti art websites and local UA tours, so that tourists gain easy access. Site also lists 15 renowned urban artists in London and thereby encouraging local artists to involve in the tourism industry. These signs show a clear victory for UA in London after a long struggle.

\section{Methods and Research Design}

Through reading this part, one will understand how the research was put into practice, bringing into consideration the sources of data, various data collection methods, overall illustration of the research strategy and the research methodology.

\subsection{Sources of Data}

This research followed a qualitative research methodology in the collection process of data. The main reason was because this research mainly deals with the thoughts, perceptions and the ideas of different stakeholders within UA and tourism circles in Madrid. The

2Obtained from http://content.time.com/time/specials/packages/article/0 ,28804,1984685_1984864,00.html 
research was carried out through an exploratory research on site, where a set of research instruments was used to answer each research sub question.

The primary source data were collected from different categories of participants (stakeholder groups) such as tourism experts, policemen, graffiti paint shop personnel, urban artists, UA tourism company guides, government supported UA project personnel, tourists to Madrid (local $\&$ international) and residents. Secondary sources of data related to the subjects of UA, UA \& tourism and the UA context in Madrid was obtained through the policy documents and by other existing academic and professional literature such as previous researches, journals and magazines.

\subsection{Data Harvesting Methods}

With regards to the primary sources of data (tourism experts, urban artists, tourists etc.), there were several ways of data collection. The first was through interviews as well as through informal conversations, where both methods were carried out mainly Spanish and also in English. Interviews in a semi structured pattern helped the researcher to stand by the basis of a theme while being open to the participants' own additional input on the relevant theme. During the contact with the different categories of interviews the researcher obtained the transcripts and recordings.

The data collection process from the primary source data also used the survey method, through the mode of a short questionnaire (Spanish or English). The short questionnaire was also so that categories of participants were able to express their own ideas on specific themes.

In addition to the interviews and survey methods, the researcher used observation of everyday reality in Madrid for data collection. Observation was mainly done to get the knowledge on the types of UA and locations as well as to observe urban artists in Madrid at work. Observation also included a participation in an UA tour organized by an UA tourism company. Through participating in this tour, the researcher was able to get a broader understanding on the UA types.

Further, the academic literature and the additional sources of data (derived from the media, internet etc.) were also examined through document analysis.

\subsection{Research Layout}

Figure 1 below explains how the field research was carried out through its layout. Each blue box represents a specific category of participants or/and institutions. The lay-out is explained below.

- Policy context of Urban Art (UA) in Madrid; This category represents the spheres revolving around the current policy situation of UA and tourism segments in Madrid.

- Creators of UA in Madrid; This category shows the actors who are creating their own art pieces in the city.

- $\quad$ Actors \& Institutions supporting UA in Madrid; As the name suggests, this category shows an overview of the people who contribute to the development of UA in Madrid.

- Societal perception on UA in Madrid; The final category takes into consideration the viewpoints of several societal groups in Madrid, who are not related to UA creations (3rd parties).

Numbers represent the number of participants approached in each stakeholder group. If a number is not present, the approach has been limited to merely one actor/ institution. Next to each participant group name, the instrument/s which data was collected is/are mentioned in brackets.

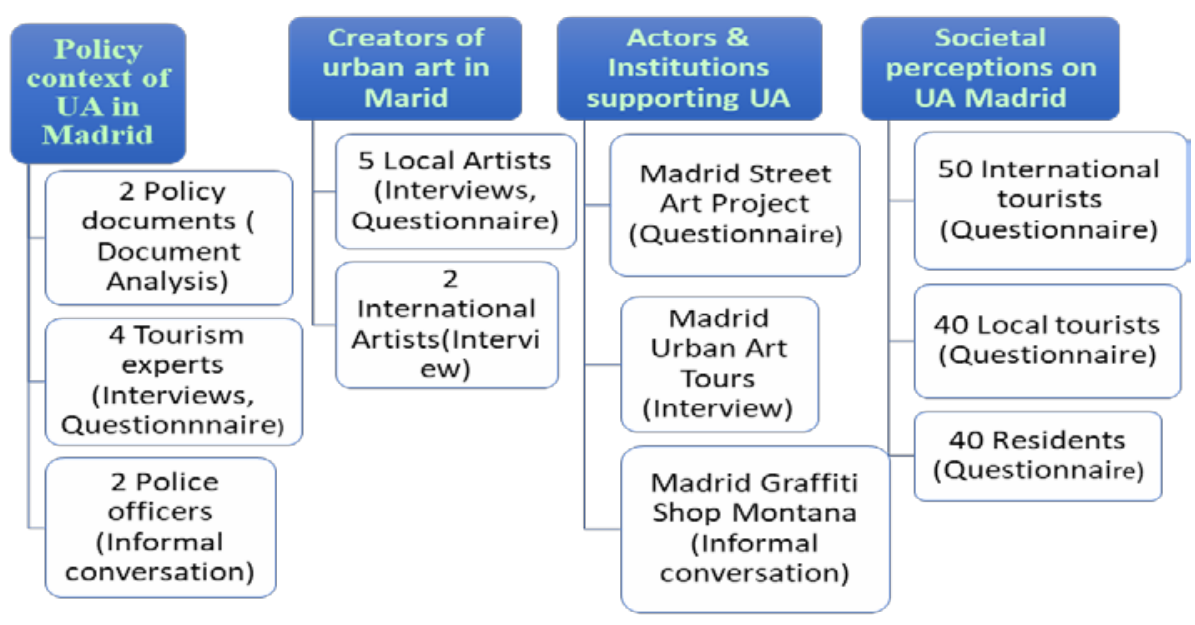

Figure 1. The structure of the research layout of the fieldwork (Source; author) 
The following subsections explain the research procedure. The research was carried out during a period of two weeks and most of the data was collected during this time frame.

\subsection{Methodology}

\subsubsection{Policy Context of Urban Art (UA) in Madrid}

- During the field research, the researcher visited Centro de turismo Madrid $^{3}$, situated in the public square Plaza Mayor. I received two policy documents for Madrid's tourism, namely the 2012-2015 and 2015-2019 tourism development plans to be critically evaluated.

- Together with the necessity of contacting government administrators of Madrid's tourism, it was intended to get a more neutral perception on the UA scene and on Madrid's tourism from a policy maker point of view. The best stakeholder group for this task were the tourism experts employed in UNWTO (United Nations World Tourism Organisation) in Madrid. Before the field research began, the tourism experts were approached for an onsite interview by email. Three tourism experts of three departments were interviewed on a semi-structured format.

- While collecting data in Madrid, the researcher had a conversation with two Police personnel.

\subsubsection{Creators of UA in Madrid}

- The researcher got in touch with five urban artists before field research by email or through social media. Due to the inability of meeting on site, the survey method was used for three artists through a semi structured; short questionnaire sent by email and for one artist I adopted a semi structured interview format. He was met in person. The last interview was carried out via a Skype interview.

- During the field research, the researcher observed urban artists (local and international) at work in the La Latina community centre (Image 2) and he got their ideas through a interview.

\subsubsection{Actors \& Institutions Supporting UA in Madrid}

During the field research, it was also aimed at meeting the stakeholders of institutions who support the UA scene in Madrid.

- $\quad$ Madrid Street Art Project (MSAP) ${ }^{4}$ is a government supported public-private organization (initiated in September 2012) dedicated to promote, support and add value to UA through implementation of projects. The short questionnaire was in the semi- structured with many open questions.

3 English translation- Madrid tourism center

4 From the website www.madridurbanarttours.com
- $\quad$ Madrid urban art tours (MUAT) ${ }^{5}$, is an UA tourism company, solely owned by a French expat who lives in Madrid. He promotes Madrid's UA in the form of tours for the tourists who are interested, since January 2016. The researcher interviewed the owner of MUAT with the help of a semi-structured format (interview lasted 20 minutes) after participating in his UA tour, mostly with open questions.

- Madrid graffiti shop Montana ${ }^{6}$ (MGSM) is a part of Montana Colors, a company witnessing to the expansion of graffiti in Madrid and partly responsible for the UA evolution in the city. Therefore, MGSM was visited and an informal conversation was carried out with the manager.

\subsubsection{Madrid's Societal Perceptions on UA}

- One of the most important tasks in the field research was to investigate how the society perceives the Madrid's UA scene. For this task, the researcher chose to approach 50 foreign tourists, 40 local tourists from other cities and 40 Madrilenian using a survey type short questionnaire as the data collection tool. There were several purposes of reaching these three categories of participants. The researcher wanted to examine, how people in society not related to the UA scene perceive Madrid's UA, whether Madrid's UA is sufficient enough to be called an attraction and to evaluate the perceptions of the society on urban artists as tourism stakeholders. In order to implement this step, the researcher spent seven days in in Madrid.

\section{Results \& Discussion}

The parts up to now have covered the introduction to the topic, the literature discussed on the subject area and the research methodology. This part will reflect on the relevance of the findings to the research questions and sub-questions relating to the theoretical framework.

\subsection{Current Capacity of UA in Madrid}

\subsubsection{UA Types, Locations and Uniqueness}

The UA scene in Madrid has become a striking contemporary art culture in the recent past. It appeared first in 1983, starting with graffiti (Abarca, 2012). During the research, it was seen that UA in Madrid has gradually expanded to various other types such as murals, stickers, wheat white posters, tagging, stencil, yarn bombing, street installation and legal walls similar to what Belgun, 2013) on the modern types of UA. Researcher observation and answers of urban artists revealed that UA pieces are spread

5 Information on MUAT was collected during the MUAT tour (See CD) 6 From the MUAT website www.montanacolors.com 
across the whole city in touristic as well the non-touristic neighbourhoods (barrios) such as Lavapies, Malasana, El Rastro, Chueca and Usera.

After speaking to different groups of UA stakeholders, it is right to say that Madrid's urban art is unique in its own special way. Dourone, an international artist from France (Image 11) and Madrid Street Art Project (MSAP) are clearly seeing Madrid having its own unique UA style compared to other European cities such as London, Berlin and Barcelona. "Luckily, globalization has not hit street art in Madrid yet as in other cities" states Guillermo de la Madrid, the chief person of MSAP, stressing that Madrid UA is unique due to its non-globalized nature. Sabek, an urban artist, affirms what Guillermo said, "Madrid's urban art is unique to others because Madrid's artists entirely draw using passionate expressions and not to show any political or social message like in London". This remark confirms that the role of UA of developing a person's identity through pseudonym (Othen-Prince, 2006).

\subsubsection{Current Law Relating to UA}

In the absence of a municipality official, the conversations with the tourism experts in UNWTO and the police officials were helpful in comprehending the current law with regards to UA. Miguel Rivera, quality and performance auditor in UNWTO specified "The current law in Madrid doesn't allow drawing urban art in public places and it is considered as vandalism. But there are certain places in Madrid dedicated to urban art and are legal". His answer was echoed also during the short conversation with the policemen, from the department la guardia civil, who added that in the historical and old parts in the city that UA creations are not allowed but allowed in other parts.

The current power devolution of Spain was also mentioned by Rivera who stated "Spain has 17 communities where Madrid is just one. The community of Madrid allows each local municipality (out of 179 in Madrid) to decide on the maintenance of urban art within their own boundary”. This system seems as a much complex one where there is a long administrative hierarchy but on the other hand, this provides each urban artist to first be recognized through his/her local municipality and then take the next step to create pieces in the community of Madrid.

\subsubsection{UA in the City Tourist Plan}

Madrid has been having five-year tourism development plans, recently from 2011-2015 and the current plan from 2015-2019. The 2012-2015 tourism plan focused on six themes, namely art \& cultural heritage, gastronomy, entertainment, nightlife, commerce \& shopping and other special products (esmadrid, 2012). In the 'art \& cultural heritage' theme, the policy mainly focused on the world-renowned art museums in Madrid. It is however important to note that UA was not a part of this plan in any one of the mentioned themes in it.

In the current tourism development plan 2015-2019, there is a significant change in the approach of tourism themes. Madrid has been divided into 14 strategic themes instead of six (munimadrid, 2015). Among these 14 themes, 'arts \& culture' and the 'neighbourhoods of Madrid' are two themes. It is striking to see that "modern and contemporary art" is included as a strategic instrument under the theme arts \& culture and "modern and urban Madrid" also being mentioned under the theme 'neighbourhoods of Madrid'. This shows that the government is having interest in promoting contemporary art in Madrid by including it in the policy document. However, what is not clear is whether 'modern and contemporary art' includes UA and whether the government is going to promote UA on an extensive basis.

\subsubsection{Can UA in General Be Used as a Tourism Tool?}

From the interviews with the UNWTO personnel, it is clear that the authorities are considering UA in general as a tourism development tool. "Absolutely, Street art has been gaining more and more recognition as a tourism tool which is shown through a variety of examples of street art exhibitions of permanent and temporary character aimed at visitors in many regions" highlighted Jelena Novakavic, sustainable strategist at UNWTO. Jelena elaborated further on the reasons why UA is increasingly attracting tourists by saying "Other than the obvious appeal of artistic expression, the main reason behind the attractiveness of street art as a tourism tool is that in majority of cases it holds an element of storytelling, an element of narrative". However until now, the UNWTO has not participated or implemented an initiative on UA tourism. The maximum level that the world's biggest tourism organization has influenced UA is when certain speakers have mentioned UA tourism in their conference papers. With relation to Madrid, the organization had implemented a project on city tourism in 2013, named "Madrid precious time", with the business stakeholders in Madrid. Sandra Carvao, head of communications-UNWTO mentions "Through events like we did with Madrid city, urban art can be indirectly influenced for recognition". But it is clear that UNWTO will not get involved in any projects in the future specifically related to UA tourism.

\subsubsection{Current Involvement of UA Creators}

The conversations with the local urban artists helped to reveal their background information and the manner they create their UA pieces in Madrid. Almost all the local artists (80\%) were Madrilenians and were born in the city periphery.

Some of local urban artists are creating both legal and illegal art pieces while the others are only creating legal art. Sabek was one of the artists who mentioned, "I do illegal and legal stuff both. That is why I don't want to show my face if you are taking a photo of me" (Image 10). Sabek's 
statement again brings out the risk factor that urban artists have to face on a daily basis.

Since MSAP is one of the main government-supporting institutes, the results also focus on the role played by this institution to uplift the UA scene in Madrid. Guillermo de la Madrid mentioned this in his own words, "I think we help artists by organizing and supporting projects where artists can take part and work in a fair way, giving time to develop their projects and become professionals".

\subsubsection{Obstacles Faced by UA Creators}

The research aimed to reveal whether there are some obstacles that the urban artists face from the government when creating UA pieces. Without any exception, all urban artists as well as MSAP agreed that there are obstacles, which have reduced relatively compared to the past. Artist Boas Mistura narrated a story where they had to pay a fine of $6000 €$ for painting a grey art piece named "Blue sky" in a grey colored wall. Artist Borondo mentioned that the previous local government arrested him for painting the street and fined but after a few years asked him to get involved in a street art project. "I feel that is dumb" he said. "The new government is spending more money for legal art and providing better facilities for urban artists than earlier" further stated Borondo. Borondo's statement proves the fact that UA changes the way of perception of governments (Kostov, 2014).

\subsection{Exploring the Extra Capacity of UA in Madrid}

\subsubsection{Can Madrid's UA Become a Tourism Tool?}

Most of the UA stakeholders, including the experts from UNWTO, artists and MSAP agree to the fact that UA in Madrid can be further enhanced as a tourism development tool. Jelena Novakovic stated, "In recent years the quality of street art in Madrid has greatly improved with a much more sophistication in expression, content and presence. The Madrid Street Art Project is a good example of how creative design can lead to complement tourist offer and enhance visitor." This comment shows that the tourism experts in UNWTO know about MSAP and how it helps Madrid's UA upliftment (even though it can be sometimes objective).

Guillermo from MSAP highlighted that UA in Madrid should be important for the locals rather than tourists, "I understand it may become attractive for tourism, but I consider street art as something positive specially for locals. I would like street art to become a tourism tool and as you say, as it will probably will”. Guillermo's statement gives a valuable insight to what MSAP actually does. MSAP aims to promote UA in Madrid as an aesthetic element primarily for locals.

Field research carried out with the tourists (international and local) and the Madrilenians revealed their preferences whether they found Madrid's UA pieces as attractive. It was exposed that most of the foreign tourists (82\%) as well as the local tourists and residents (80\%) had seen the UA pieces in the city as attractive or had not seen the pieces yet but were willing to stop to see the next time. One local tourist mentioned " Urban art gives life to Madrid by its colourful designs. It makes the ugly walls pretty”. The talent of Madrid' urban artists were mentioned by a foreign tourist who stated "The craftsmanship of the artist is to be seen in UA because most of the art is done with a meaning written behind".

The survey carried out with the tourists and residents also found out one's desire to recommend the UA scene in Madrid to family and friends. Results showed a similar pattern to the attractiveness of Madrid's UA pieces, where majority of the foreign visitors (80\%), local tourists (92.5\%) and Madrilenians (83.3\%) would recommend the urban art gladly to their families and friends. One of the residents in Madrid gave the reason as to why she would recommend the UA to family and friends, "Madrid has a nice type of art which brings a new landscape to the city environment" she said. Another local tourist stated, "A promotion to friends and family will be responsible for them to see another characteristic and another form of Madrid's culture".

\subsubsection{Future Aspirations of the UA Creators}

The five urban artists were open enough to reveal their future aspirations. It is concluded that some of the artists have concrete plans to combine their artistic talent for future development while others create urban art pieces not of any future ambition. Artist Somos1984 didn't have any idea on his future plans were and had decided to live day by day. Artists Boas Mistura and Dos Jotas revealed that they would give the city squares more colour and continue to work more freely and critically in the future. Borondo says 'I would return to Madrid only if the national government in Spain changes'. His statement clearly indicates that overall attitude in Spain on the subject also needs to be changed.

\subsubsection{UA Stakeholder Views on Urban Artists Being Guides}

Different categories of participants were inquired on what they think about urban artists accompanying tourists in Madrid as guides. When asked from the artists, the opinion differed from one to another. Dos Jotas and Boas Mistura found urban artists leading tourists as guides as a positive idea, while Boas Mistura was himself already guiding tourists. Somos1984 was of the idea that guiding is different to being an urban artist and that there are already people specializing in organizing urban art tours.

It was also seen that a high number of international tourists (64\%), Madrilenians (80\%) and the local tourists (95\%) were positive on the idea on Madrid's urban artists working as guides to accompany visitors to show their art pieces. One Madrilenian stated "urban artists know better than anyone over their works and also about the explanations and therefore will do a better job". It was 
appropriate to ask the MSAP on how they are helping the urban artists to achieve this desire. During the contact with MSAP, it was suggested that MSAP personnel are leading their tours. Guillermo mentioned, "We guide our tour ourselves. We haven't considered including the artists in our tours"

\subsubsection{Gaps for Improvement}

MSAP does not use urban artists as guides in their UA tours. This can be considered as a lost opportunity for urban artists and the research proves this should be provided for the urban artists.

The results of the research show that there is no proper official method to recognize an urban artist in Madrid even though there is a procedure to make legal UA pieces. The lack of a proper system to recognize potential urban artists demands the need of a proper recognition plan such as licenses.

It is not only MSAP that mediates UA talent with city projects in Madrid. According to Guillermo, there are other three similar public projects named Paisaje Tetúan, Paisaje Sur and Paisaje Vallecas. This is a good sign that more and more government-supported organizations such are being initiated in Madrid for UA but the need is for closer collaboration within parties.

A specific problem was found when talking to Chris Pears of . He pointed at some errors of UA tours of MSAP saying that those tours are only conducted in Spanish and emphasized on the lack of techniques to guide visitors. This is a stride between two private UA supporting institutions, arisen due to the administrative system.

\subsection{How to Realize the Extra Capacity of UA?}

\subsubsection{Through the City Tourism Plan}

The results of this research show that the new local government of Madrid, which came to power in May 2015, has been supportive towards the UA scene in Madrid. However, with relation to the policy documents, the inclusion of "modern and contemporary art" and "modern and urban Madrid" does not necessarily mean that UA is exclusively a part of Madrid's new tourism development plan 2015-2019. Also, the new tourism development plan is just limited to a presentation ${ }^{7}$ and does not elaborate specific theme objectives used for tourism. Therefore, it brings the necessity to specify the relevant micro level steps to uplift the UA scene in Madrid..

As for the future is concerned, it was realized through the expression of Guillermo that the increasing influence of $\mathrm{UA}$ as a tourism instrument will have an impact on the

7 http://www.madrid.es/UnidadesDescentralizadas/UDCMedios/noticias/ 2015/01en

ero/15Jueves/Notasprensa/BotellaPlanTurismo/ficheros/PLAN\%20TURI $\mathrm{SMO} \% 2$

0DOCUMENTACI\%C3\%93N\%20ADJUNTA.pptx city's next tourism development plan in 2019. He stated "There will probably be some intention to include street art specifically in the tourism policy in the coming years, but I hope that is done respecting the street art culture and letting tourists enjoy it freely". Guillermo's statement brings a ray of hope for the UA lover because the influence of UA tourism in Madrid is in the upward trend and expected to become more influential in the future. So the new policy document in 2019 should include UA and specify objectives.

\subsection{Through Whom Should the Extra Capacity be Realized?}

\subsubsection{Local Urban Artists}

One realizes through the views of the local urban artists that there are several measures that the government can do directly to support the UA scene in Madrid. Somos1984 stated that more support is needed through advertising, financing and fostering central locations for urban artists to paint freely. Dos Jotas also emphasized on financial support. As Borondo suggested, it is important that the government stipulate more budgetary allocations for projects such as MSAP and take maximum benefits out of those institutions, which will in turn benefit the artists financially.

\subsubsection{MSAP}

It was observed in section 4.2 that some of the local urban artists like the idea of simultaneously being a guide and it was also seen that MSAP is not using urban artists as guides. The government of Madrid can intervene in this situation to give advice and encouragement to projects like MSAP to use the service of local urban artists for guiding services.

\subsubsection{MUAT}

This research also found out that the government support has been always very minimal to private UA institutes like MUAT. Chris Pears had a negative feeling on the subject. "In Madrid it is very difficult for a foreigner to carry on a business. I mean for me, it has been hard to talk to the government officials on supporting my tours. They say that they will do but always fail to do". Chris' remark suggests that the local government of Madrid is mostly working with the known, local partners such as MSAP for the development of UA. Also it was seen that more locals and residents find Madrid's UA attractive than foreigners.

\subsubsection{UNWTO}

The tourism experts had clearly given the idea that UNWTO has not been associating the subject of UA explicitly in the past. UNWTO's main aim is not to promote UA at the first place and they have done minimal efforts to support, develop or encourage stakeholders on $\mathrm{UA}$ in general. 


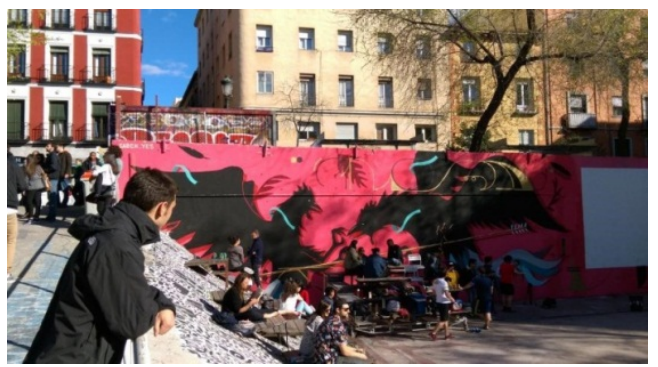

Image 10. Local Urban artist Sabek with his face not shown, Madrid (Source, Researcher)

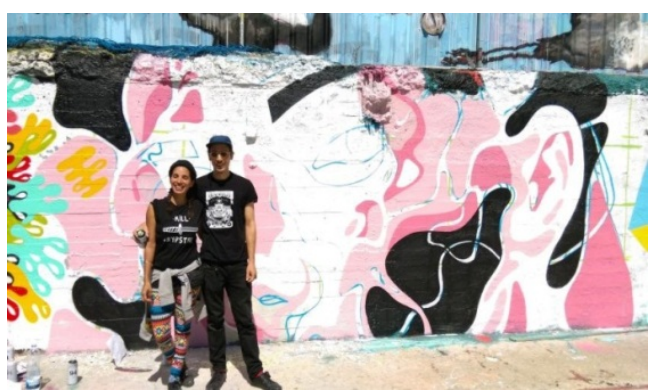

Image 11. International Urban artists Dourone in La Latina, Madrid (Source, Researcher)

\section{Conclusions \& Recommendations}

With the status quo as it is from the results in the previous part, this part contributes by applying the findings of this research and their implications to real world policy makers.

\subsection{Answering the Research Questions}

People in the city take their creative ideas and shape them into places and experiences that are the essence of a vibrant city. It is in this context that this research of Madrid's urban art (UA) was undertaken. In the first part of this research, the main research questions are posed. "“Does urban art in Madrid have the capacity to be developed as an attraction for the visitor who comes to Madrid and, if that is so, how and through whom can these capacities be realized?"

We answer these questions below through giving the following policy recommendations.

\subsection{Suggested Policy Recommendations}

For the local government of Madrid

To explicitly mention whether UA is included under the themes 'contemporary art' and 'urban Madrid' in the city tourism plan 2015-2019, not merely limiting to a presentation, and if it is so, to specify the relevant objectives on integrating UA scene in Madrid as a tourism tool.
- Work on UA and UA related activities in the proposed tourism policy document for Madrid for 2019-2023 supporting all stakeholders.

- Showing full support for the promotion of UA through erasing the ambiguous 'fake freedom' (Toronto city hall, 2016) with the support of the urban artists themselves.

- Continue develop UA in Madrid as a tourism development tool for the local tourists as well as the Madrilenians, with more financial help for government supported projects such as MSAP.

- Granting permission for more unused spaces in the city (ex; junkyards, public parks) to be used as community centres and thereby permitting legal UA creations for artists.

- Implementing a proper structure to give urban artists recognition through a permit or a license, based on the quality of the art pieces created by the artist.

- Set up an UA museum in Madrid, with the art creations of local urban artists for the further development of UA and to attract more urban art lover tourists to Madrid.

\section{For the UNWTO}

- A future publication or event related to UA tourism is recommended and thereby helping national governments realize the importance of this art type and work on it on a global basis.

\subsection{Limitations}

This research encountered some limitations, which can be mentioned in order to improve this research further and use it for future investigations on the subject. First of all, it was not possible to contact a municipality official or any tourism official in the Madrid tourist office to discuss on how UA is framed in a municipality level or to discuss about UA in Madrid from a government tourism official's perspective. This limitation lead the research to be carried out with alternative policy makers such as the UNWTO officials. Secondly, not all neighbourhoods in Madrid were visited to observe UA pieces, due to the non-accessibility with public transport and limited time factor. Thirdly, the distinct lack of scholarship on UA tourism created a small void in data, where very many media publications were substituted. That was the reason to study this topic.

\section{Glossary}

Urban art- (UA): This is a form of contemporary art in public places, mostly in urban areas. Artists create UA in the forms of paintings, signatures, stickers, drawings, murals, and graffiti among other types to express their ideas, perceptions, thoughts and concepts. 
Urban artists: The creators of the UA pieces are called by this name.

Piece; this is the singular term used to describe one of the UA creation. A piece can be a one of the types mentioned above in UA definition.

Graffiti art: This is a sub type of UA. When one writes or scrabbles for a sentence or a name in public places, we call it graffiti. Graffiti is mainly drawn to mark territory.

Tagging: This is a way of expression to identify the urban artist's unique identity. Tagging is usually seen next to the piece by writing the name of the artist literally or through a characteristic symbol.

Tourism development plan; It is a long-term strategy created to develop the tourism potential of a destination, usually five to ten years.

Urban art tourism: Any type of tourism activity or a place (ex; urban art tours, urban art museums) related to the prevalence of urban art in a city belongs to urban art tourism

\section{REFERENCES}

[1] Abarca, J. (2012). Madrid Revolution; the History of the capital. (1st ed.). Madrid: Montana colors original.

[2] Allen, J. (2013). 14 Street Art Terms-Illustrated!. Retrieved 2 June, 2016, from http://mentalfloss.com/article /51583/14-street-art-terms\%E2\%80\%94illustrated

[3] Baillie, E. (2014). A Look at the Vibrant Street Art Scene in Buenos Aires,

[4] Argentina. Retrieved 1 June, 2016, from http://untappedcities.com/2014/08/11/a-lookat-the-vibrantstreet-art-scene-in-buenos-aires-argentina/

[5] Belgun, A. (2013). Seven Inspiring Street Artists That Give Art a New

[6] Meaning. Retrieved 3 June, 2016, from http://www.tourismontheedge.com/getcultural/street-artists

[7] Ganz, N. (2006). Graffiti Woman : Street Art from Fi

[8] ve Continents. (1st ed). England: Thomas and Hudson.

[9] Hughes, M.L. (2009). Street Art \& Graffiti Art: Developing an Understanding. (1st ed). Retrieved 2 June, 2016, from

[10] http://scholarworks.gsu.edu/cgi/viewcontent.cgi?article=10 49\&context=art_design_the ses

[11] Infamous Spanish graffiti artist arrested over '31,000 euro damage. (2013)Retrieved 5 June, 2016, from http://www.euronews.com/2013/11/05/spanish-police-arre st-31-000euros-damage-graffiti-artist/

[12] Keays, C. (2015). Is urban graffiti a force for good or evil? Retrieved 4 June, 2016, from http://www.theguardian.com/ cities/2015/jan/07/urban-graffiti-force-goodevil

[13] Lewisohn, C. (2008). Street art; The graffiti revolution (pp 31). (1st ed.). Baltimore: Chalfont.
[14] Madrid visitors and convention burueau. (2015) Documentación Plan Estratégico de Turismo 2015-2018. Retrieved 1 June, 2016, from http://www.madrid.es/portale s/munimadrid/es/Inicio/Buscador?vgnextfmt=default\&vgn extchannel=d4cade31bd2ac410VgnVCM100000171f5a0a RCRD\&action $=$ com.munim

[15] adrid.waf.portlet.action.SearchAction\&q=plan+estrategico +turismo\&vgnextoid $=\mathrm{d} 4 \mathrm{cad}$ e31bd2ac410VgnVCM100000171f5a0aRCRD

[16] Madrid visitors and convention burueau. (2012). Plan Estratégico de Turismo 20122015. Retrieved 1 June, 2016, from

http://madridvcb.esmadrid.com/sala-deprensa/plan-estrateg ico-de-turismo-2012-2015

[17] Neves, P \& Semoes, D. (2015). -. Street Art \& Urban Creativity Scientifc Journal, 1(1), 13-26. Retrieved 7 June, 2016, from

[18] http://www.urbancreativity.org/uploads/1/0/7/2/10727553/ journal2015_v1_n1_web_final_upt. 